\title{
Corn germ with pericarp in relation to whole corn: nutrient contents, food and protein efficiency, and protein digestibility-corrected amino acid score
}

\author{
Gérmen de milho com pericarpo em relação ao milho inteiro: conteúdo em nutrientes, eficácia \\ alimentar e protéica e digestibilidade protéica corrigida pelo escore de aminoácido
}

\author{
Maria Margareth Veloso NAVES ${ }^{1 *}$, Maiza Vieira Leão de CASTRO², Aline Luiz de MENDONÇA², \\ Grazielle Gebrim SANTOS², Maria Sebastiana SILVA²
}

\begin{abstract}
The germ fraction with pericarp (bran) is generated in the industrial processing of corn kernel, and it is used for oil extraction and animal feed. This study evaluated the nutritional and protein quality of this fraction in relation to whole corn. The proximate composition, mineral contents, and amino acid profile of the germ fraction with pericarp and of whole corn were determined. A 4-week experiment was conducted using 36 weanling male Wistar rats, and three 10\%-protein diets (reference, germ with 15\% lipids and casein with 15\% lipids), two 6\%-protein diets (whole corn and casein), and a protein-free diet were prepared. The germ showed higher contents of proteins, lipids, dietary fiber $\left(27.8 \mathrm{~g} .100 \mathrm{~g} \mathrm{~g}^{-1}\right)$, ash, minerals (Fe and Zn- approximately $\left.5 \mathrm{mg} .100 \mathrm{~g}^{-1}\right)$, and lysine $\left(57.2 \mathrm{mg} \mathrm{g}^{-1}\right.$ protein) than those of corn. The germ presented good quality protein (Relative Protein Efficiency Ratio-RPER $=80 \%$; Protein Digestibility-Corrected Amino Acid Score-PDCAAS $=86 \%$ ), higher than that of corn (RPER $=49 \%$; PDCAAS $=60 \%)$. The corn germ fraction with pericarp is rich in dietary fiber, and it is a source of good quality protein as well as of iron and zinc, and its use as nutritive raw material is indicated in food products for human consumption. Keywords: Zea mays; maize; nutrients; protein; amino acids; biological evaluation.
\end{abstract}

\section{Resumo}

A fração gérmen com pericarpo (farelo) é produzida no processamento do grão de milho, sendo usada para extração de óleo e alimentação animal. O estudo avaliou a qualidade nutricional e proteica desta fração em relação ao milho. Foi determinada a composição centesimal, conteúdo em minerais e perfil de aminoácidos da fração gérmen com pericarpo e do milho. Foi conduzido um experimento (4 semanas) com 36 ratos Wistar machos recém-desmamados, e foram formuladas três dietas contendo 10\% de proteína (referência, gérmen com 15\% de lipídios e caseína com $15 \%$ de lipídios), duas dietas com $6 \%$ de proteína (milho e caseína), e uma dieta aproteica. Foram constatados maiores teores de proteínas, lipídios, fibra alimentar $\left(27,8\right.$ g. $\left.100 \mathrm{~g}^{-1}\right)$, cinzas, minerais (Fe e Zn - aproximadamente $\left.5 \mathrm{mg} .100 \mathrm{~g}^{-1}\right)$ e lisina $\left(57,2 \mathrm{mg} \cdot \mathrm{g}^{-1}\right.$ proteína) no gérmen em relação ao milho. O gérmen apresentou proteína de boa qualidade (Relative Protein Efficiency Ratio-RPER = 80\%; Protein Digestibility-Corrected Amino Acid Score-PDCAAS = 86\%), superior à do milho (RPER = 49\%; PDCAAS = 60\%). A fração gérmen com pericarpo é rica em fibra alimentar e é fonte de proteína de boa qualidade e de ferro e zinco, sendo indicado seu uso como matéria-prima nutritiva em produtos alimentícios para consumo humano.

Palavras-chave: Zea mays; milho; nutrientes; proteína; aminoácidos; avaliação biológica.

\section{Introduction}

Corn is the second most widely produced cereal in the world. Much of this production is used for animal feed, especially in developed countries. Only a small proportion (10 to $15 \%$ ) is consumed directly as food or processed to produce byproducts such as starch, flours, hominy, cornflakes, and syrups (WATSON; RAMSTED, 1999).

The corn kernel is made up of four main structures: the pericarp (bran), endosperm, germ (embryo), and the tip. Corn contains 8 to $11 \%$ of protein with lower lysine content (usually less than $30 \mathrm{mg} \cdot \mathrm{g}^{-1}$ protein) than other cereal grains such as rice or wheat (FOOD..., 1970; SOTELO et al., 1994; SHEWRY, 2007). While most corn protein (75\%) comes from the endosperm, it is in the germ that the proteins with the best amino acid profile are concentrated. Those proteins present about three times more albumin, twice as much globulin, and ten times less zein than the whole kernel (GUPTA; EGGUM, 1998; SHEWRY, 2007).

In the industrial processing of corn, the kernel is degermed and the amylaceous endosperm, which is of the greatest interest to the food industry, is separated from the other fractions. The most important fraction is made up of the germ with pericarp, generally used for oil extraction and animal feed due to its high density of nutrients, particularly lipids, proteins, and fibers (BRITO et al., 2005; GUPTA; EGGUM, 1998; WATSON; RAMSTED, 1999). 
Therefore, the chemical composition of the corn germ with pericarp suggests that it has great potential as a raw material for the food industry. However, there are only a few studies about the nutritional quality of the corn germ (BRITO et al., 2005; GUPTA; EGGUM, 1998), and none of the reported studies has assessed the nutritional quality of the whole fraction (corn germ with pericarp) for human consumption. For this reason, the objective of the present investigation was to evaluate the nutritional and protein quality of this fraction in relation to the corn (whole kernel).

\section{Materials and methods}

\subsection{Samples of whole corn and corn germ fraction with pericarp}

The corn used in this study was selected among the bestselling varieties in the State of Goiás (GO, Brazil) with attractive characteristics to the milling industry such as size, color, and kernel toughness. Samples of the selected variety (30F80 Pioneer $^{\circledast}$ ) were acquired in the municipality of Paraúna (GO) and processed by a milling industry (Milhão Alimentos Ltda.) located in the city of Inhumas (GO). After the impurities were removed on a gravimetric table, a sample of whole corn $(5 \mathrm{~kg})$ was taken and milled. To obtain the corn germ fraction with pericarp (bran), the corn samples were dry-processed in three replicates as follows: the kernels were moistened at $16.4 \%$ moisture and degermed in an industrial multiprocessor (Zaccarias MPZ/AE degermer), in which the germ and the pericarp were separated from the endosperm. This fraction was dried, and a sample $(5 \mathrm{~kg})$ was collected and milled for the study.

\subsection{Chemical analyses}

The protein level in whole corn and germ fraction with pericarp, in the experimental diets and in rat feces, was determined by the total nitrogen analysis (Kjeldahl method) (ASSOCIATION..., 1990) using a factor of 6.25 to convert nitrogen into raw protein (FOOD..., 1970). The corn and the germ with pericarp were also analyzed for moisture and ash (INSTITUTO..., 2005), for total dietary fiber following Prosky et al. (1988), and for total lipids using the method described by Bligh and Dyer (1959). The carbohydrates were estimated by difference by subtracting the values of proteins, lipids, dietary fiber, moisture, and ash from 100. The minerals (calcium, iron, and zinc) were extracted from ash with concentrated $\mathrm{HCl}$ and temperature and analyzed, and they were quantified by atomic absorption spectrophotometry (spectrophotometer Varian, model SpectrAA-200) using instrumental parameters for each mineral (ASSOCIATION..., 1990).

The amino acid composition in the whole corn and germ fraction was determined at the Protein Chemistry Center of the University of São Paulo (USP, Ribeirão Preto, Brazil). The samples were acid-hydrolyzed (MOORE; SPACKMAN; STEIN, 1958), except for tryptophan which was alkaline-hydrolyzed (LUCAS; SOTELO, 1980) and placed in an automatic amino acid analyzer (Nicolas V, USP, Ribeirão Preto, Brazil). The amino acids were quantified colorimetrically (ALONZO; HIRZ, 1968). The results of those analyses were used to estimate the Amino Acid Score (AAS) on the basis of the standard established by the Food and Nutrition Board of the Institute of Medicine (2005) and were calculated as follows: mg of limiting amino acid in $1 \mathrm{~g}$ of test protein. $\mathrm{mg}^{-1}$ of same amino acid in $1 \mathrm{~g}$ of reference protein.

\subsection{Biological evaluation}

The experiment was carried out with 36 weanling male Wistar rats (21-25-days old) from the colony of the Bioagri Laboratories (Planaltina, Federal District, Brazil). The rats were randomly divided into six groups of six animals each, and the differences in mean body weight among the groups were less than $3 \mathrm{~g}$. The animals were kept in individual cages under standard environmental conditions (temperature $-23 \pm 2{ }^{\circ} \mathrm{C}$, relative humidity - 50-60\% and 12-hour light-dark cycles) for 31 days ( 3 days of acclimation and 28 days of experiment, except for a protein-free group of animals - 14 days). The diets were formulated according to the American Institute of Nutrition (REEVES; NIELSEN; FAHEY JR., 1993). The ingredients used in the formulation of the diets and their respective quantities are described in Table 1 . Three $10 \%$ protein diets were prepared:

Table 1. Ingredient composition of experimental diets.

\begin{tabular}{|c|c|c|c|c|c|c|}
\hline \multirow{2}{*}{$\begin{array}{r}\text { Ingredient } \\
\left(\mathrm{g} .100 \mathrm{~g}^{-1}\right)^{\mathrm{b}} \\
\end{array}$} & \multicolumn{6}{|c|}{ Diet $^{\mathrm{a}}$} \\
\hline & Reference & Germ control & Germ & Corn control & Corn & Protein-free \\
\hline Casein $^{c}$ & 12.81 & 12.81 & - & 7.67 & - & - \\
\hline Germ with pericarp & - & - & 83.20 & - & - & - \\
\hline Corn (whole kernel) & - & - & - & - & 81.30 & - \\
\hline L-cystine & 0.19 & 0.19 & - & 0.12 & - & - \\
\hline Soybean oil & 6.70 & 14.70 & 0.24 & 6.82 & 3.06 & 7.00 \\
\hline Cellulose & 5.00 & 5.00 & - & 5.00 & - & 5.00 \\
\hline AIN mineral mix & 3.50 & 3.50 & 3.50 & 3.50 & 3.50 & 3.50 \\
\hline AIN vitamin mix & 1.00 & 1.00 & 1.00 & 1.00 & 1.00 & 1.00 \\
\hline Choline bitartrate & 0.25 & 0.25 & 0.25 & 0.25 & 0.25 & 0.25 \\
\hline Corn starch & 70.55 & 62.55 & 11.81 & 75.64 & 10.89 & 83.25 \\
\hline
\end{tabular}

${ }^{a}$ Diets formulated in accordance with AIN93G (REEVES; NIELSEN; FAHEY JR., 1993): reference - casein with $10 \%$ protein and 7\% lipids and germ control - casein with $10 \%$ protein and $15 \%$ lipids; germ - germ fraction with pericarp with $10 \%$ protein and $15 \%$ lipids, corn control - casein with $6 \%$ protein and corn - whole corn with $6 \%$ protein. ${ }^{\mathrm{b}}$ Supplied by RHOSTER (São Paulo, Brazil), except for corn and byproducts (supplied by Milhão Alimentos Ltda., Inhumas, GO, Brazil). ${ }^{\circ}$ Casein with $78.06 \%$ protein and $2.35 \%$ lipid. 
casein with 7\% lipids (reference group), germ fraction with pericarp with $15 \%$ lipids (germ group), and casein with $15 \%$ lipids (germ control group). In addition, two $6 \%$ protein diets were formulated: casein (corn control group) and whole corn (corn group). A protein-free diet was also prepared. The food consumption was controlled and the body weight of the rats was assessed three times a week. The experiment was conducted in accordance with the guidelines for the care and use of laboratory animals (NATIONAL..., 2004) and was approved by the Ethics Committee in Research of the Federal University of Goiás (Protocol n ${ }^{\circ}$ 182/2009).

The experimental data were used to estimate the following indexes: Food Conversion Ratio $(\mathrm{FCR}=$ total diet consumed by a test group/weight gain of a test group) (MARTINEZ-FLORES et al., 2004), Protein Efficiency Ratio (PER = weight gain of test animal/protein consumed), Relative PER (RPER = PER of test animal $x$ 100/PER of reference group), and Corrected PER (PER of test animal x 2.5/PER of reference group) (PELLETT; YOUNG, 1980). The RPER was estimated by using $10 \%$ protein-casein groups (for the germ group) and $6 \%$ protein-casein group (for the corn group) as the reference groups. To correct the germ group's PER value, the $10 \%$ proteincasein group with 7\% lipids was taken as the reference group and 2.5 as the standard value for casein (PELLETT; YOUNG, 1980). In addition, the true protein digestibility (\%) was calculated as recommended by the FAO for in vivo tests (FOOD..., 1991). For this index, each rat's feces was collected during the second week of the experiment, oven-dried $\left(100{ }^{\circ} \mathrm{C}\right.$ for 24 hours), and ground for nitrogen analysis. The Protein DigestibilityCorrected Amino Acid Score (PDCAAS) was also estimated as follows (INSTITUTE..., 2005): AAS of test protein $\mathrm{x}$ true protein digestibility of test animal (\%).

\subsection{Statistical analysis}

The data are presented as means \pm standard deviation. The results of the chemical analyses (proximate and mineral compositions of germ fraction with pericarp and whole corn) and of the 6\%-protein diet groups (corn and corn control) were compared using the Student's $t$ test for unpaired samples. Analysis of variance and the Tukey mean-comparison test were used to analyze the data of the rats on a $10 \%$-protein diet (reference, germ and germ control groups). STATISTICA software (StatSoft, Inc., Tulsa, OK, version 7.0, 2004) was used for the statistical analyses. Differences were considered significant when $\mathrm{p}<0.05$.

\section{Results and discussion}

The proximate composition of the germ fraction and the whole corn is given in Table 2. The germ fraction with pericarp showed higher levels of proteins, lipids, dietary fiber, ash, and minerals (calcium, iron and zinc) than those of the whole corn. The total dietary fiber on dry matter basis for the germ fraction with pericarp was $30 \mathrm{~g} .100 \mathrm{~g}^{-1}$. Therefore, this fraction may be considered a fiber-rich raw material with higher dietary fiber content than that of oat bran $\left(18 \mathrm{~g} .100 \mathrm{~g} \mathrm{~g}^{-1}\right)$ and lower than that of wheat bran (43 g.100 g ${ }^{-1}$ (GRÅSTEN et al., 2002).
It was also observed that the germ fraction contains

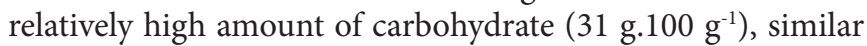
to that reported for defatted maize germ (around $35 \mathrm{~g} .100 \mathrm{~g}^{-1}$ ) (GUPTA; EGGUM, 1998). This unexpected high amount of carbohydrate in the germ fraction may be the result of an incomplete separation of kernel structures during the industrial processing of corn, resulting in a germ fraction with pericarp and endosperm fragments. Furthermore, the high contents of iron and zinc (approximately $5 \mathrm{mg} .100 \mathrm{~g}^{-1}$ ) in this fraction suggest that it is a good source of those minerals (Table 2).

The germ fraction presented a good indispensable (essential) amino acid profile with higher level of lysine (57.2 mg. $\mathrm{g}^{-1}$ protein) than the reference value, and its lysine level was approximately $50 \%$ higher than that of whole corn (Table 3 ). Moreover, the proteins of the germ fraction with pericarp showed higher level of lysine than that reported by Gupta and Eggum (1998) for defatted maize germ (49.7 mg.g ${ }^{-1}$ protein), a byproduct of the corn oil extraction industry. The level of lysine found in whole corn ( $37.9 \mathrm{mg} . \mathrm{g}^{-1}$ protein) is also higher than the values reported in the literature for common corn, which varie from 26 to $30 \mathrm{mg} . \mathrm{g}^{-1}$ protein (FOOD..., 1970; GUPTA; EGGUM, 1998; NAVES et al., 2004; PIRES et al., 2006; SHEWRY, 2007). The dispensable/conditionally indispensable amino acid contents of germ were higher than those of whole corn, mainly due to aspartic acid, arginine and glycine levels, as shown in Table 3.

In the experiment, there were no significant differences $(p>0.05)$ in the final weight and weight gain among germ, germ control, and reference groups, as shown in Table 4 . The final weight and weight gain of the corn group were significantly lower than those of its control group $(p=0.0004$ and 0.0343 , respectively). The food intake of the germ group was significantly higher than that of the germ control group $(\mathrm{p}<0.01)$. The high fiber content of the germ diet (23\%) and the resulting high fecal loss from the germ group (Table 5) probably contributed to the higher food consumption. In turn, the higher food intake in the

Table 2. Proximate and mineral compositions of germ fraction with pericarp and whole corn.

\begin{tabular}{lcc}
\hline \multicolumn{1}{c}{ Composition } & $\begin{array}{c}\text { Germ with } \\
\text { pericarp }\end{array}$ & $\begin{array}{c}\text { Corn } \\
\text { (whole kernel) }\end{array}$ \\
\hline Proximate $\left(\mathrm{g} .100 \mathrm{~g}^{-1}\right.$ ) & & \\
$\quad$ Moisture & $8.00 \pm 0.03$ & $7.76 \pm 0.12$ \\
Proteins & $12.02 \pm 0.39^{*}$ & $7.38 \pm 0.09$ \\
Total lipids & $17.74 \pm 0.33^{*}$ & $4.85 \pm 0.14$ \\
Total dietary fiber & $27.75 \pm 1.46^{*}$ & $10.46 \pm 1.50$ \\
Ash & $3.54 \pm 0.04^{*}$ & $1.00 \pm 0.03$ \\
Carbohydrates & 30.95 & 68.55 \\
Mineral (mg.100 g $\left.{ }^{-1}\right)$ & & \\
Calcium & $18.41 \pm 1.54^{*}$ & $6.76 \pm 0.55$ \\
Iron & $5.33 \pm 0.10^{*}$ & $3.37 \pm 0.19$ \\
Zinc & $5.07 \pm 0.41^{*}$ & $2.08 \pm 0.23$ \\
\hline
\end{tabular}

Data are mean \pm standard deviation of three replicates, except for the total dietary fiber (four replicates). Carbohydrates are calculated by difference, subtracting the values obtained for moisture, proteins, total lipids, total dietary fiber, and ash from 100. ${ }^{*}$ Statistically significant differences between germ and corn (unpaired Student's $t$ test, $\mathrm{p}<0.05)$. 
Naves et al.

Table 3. Amino acid composition of germ fraction with pericarp and whole corn and Amino Acid Score (AAS) according to the FNB/IOM reference.

\begin{tabular}{|c|c|c|c|}
\hline \multirow[t]{2}{*}{ Amino acid (mg. $\mathrm{g}^{-1}$ protein) } & \multicolumn{2}{|c|}{ Protein source $^{\mathrm{a}}$} & \multirow[t]{2}{*}{ Reference $\mathrm{FNB} / \mathrm{IOM}^{\mathrm{t}}$} \\
\hline & Germ with pericarp & Corn (whole kernel) & \\
\hline \multicolumn{4}{|l|}{ Indispensable } \\
\hline Histidine & 34.3 & 38.1 & 18.0 \\
\hline Isoleucine & 36.1 & 36.3 & 25.0 \\
\hline Leucine & 75.0 & 113.6 & 55.0 \\
\hline Lysine & 57.2 & 37.9 & 51.0 \\
\hline Treonine & 46.9 & 39.5 & 27.0 \\
\hline Tryptophan & 19.4 & 15.8 & 7.0 \\
\hline Valine & 57.3 & 51.6 & 32.0 \\
\hline Total & 427.0 & 448.6 & 287.0 \\
\hline AAS & 1.12 & 0.74 & 1.00 \\
\hline Alanine & 69.4 & 79.2 & - \\
\hline Arginine & 79.4 & 57.8 & - \\
\hline Glycine & 62.3 & 41.7 & - \\
\hline Proline & 82.6 & 99.4 & - \\
\hline Serine & 47.6 & 44.6 & - \\
\hline Total & 573.1 & 551.4 & \\
\hline
\end{tabular}

${ }^{a}$ Data are means of two repetitions. ${ }^{b}$ Food and Nutrition Board/Institute of Medicine. Values are sufficient to meet the requirements of individuals in all age groups, except for infants (INSTITUTE..., 2005).

Table 4. Body weight (final and gain), food and protein intake, FCR (Food Conversion Ratio) and PER (Protein Efficiency Ratio) of Wistar rats during the 28 days of the experiment.

\begin{tabular}{|c|c|c|c|c|c|c|}
\hline \multirow[t]{2}{*}{ Diet } & \multicolumn{2}{|c|}{ Body weight (g) } & \multicolumn{2}{|c|}{ Intake (g) } & \multirow[t]{2}{*}{ FCR } & \multirow[t]{2}{*}{ PER } \\
\hline & final & gain & food & Protein & & \\
\hline \multicolumn{7}{|c|}{ With $10 \%$ protein } \\
\hline Reference & $217.4 \pm 24.8^{\mathrm{a}}$ & $126.2 \pm 13.3^{\mathrm{a}}$ & $446.6 \pm 44.9^{\mathrm{a}, \mathrm{b}}$ & $44.5 \pm 4.5^{\mathrm{a}, \mathrm{b}}$ & $3.54 \pm 0.08^{\mathrm{b}}$ & $2.83 \pm 0.06^{\mathrm{b}}$ \\
\hline Control & $206.2 \pm 35.4^{\mathrm{a}}$ & $114.6 \pm 23.0^{\mathrm{a}}$ & $375.3 \pm 68.0^{\mathrm{b}}$ & $37.5 \pm 6.8^{\mathrm{b}}$ & $3.29 \pm 0.16^{c}$ & $3.04 \pm 0.15^{\mathrm{a}}$ \\
\hline Germ & $199.7 \pm 24.0^{\mathrm{a}}$ & $108.4 \pm 13.2^{\mathrm{a}}$ & $475.8 \pm 49.0^{\mathrm{a}}$ & $46.3 \pm 4.8^{\mathrm{a}}$ & $4.40 \pm 0.17^{\mathrm{a}}$ & $2.34 \pm 0.09^{c}$ \\
\hline \multicolumn{7}{|c|}{ With $6 \%$ protein } \\
\hline Control & $167.6 \pm 10.8$ & $79.6 \pm 3.7$ & $410.0 \pm 13.1$ & $25.8 \pm 0.8$ & $5.16 \pm 0.28$ & $3.08 \pm 0.17$ \\
\hline Corn & $116.1 \pm 16.8^{*}$ & $30.7 \pm 9.2^{*}$ & $331.6 \pm 48.3^{*}$ & $20.4 \pm 3.0^{*}$ & $11.53 \pm 3.26^{*}$ & $1.50 \pm 0.33^{*}$ \\
\hline
\end{tabular}

Diets: reference - casein with $10 \%$ protein and 7\% lipids; germ control - casein with $10 \%$ protein and $15 \%$ lipids; germ - germ fraction with pericarp, with $10 \%$ protein and $15 \%$ lipids; corn control - casein with $6 \%$ protein; and corn - whole corn with $6 \%$ protein. ${ }^{\mathrm{a}, \mathrm{b}, \mathrm{c}}$ Data are mean \pm standard deviation and means with the same letter in the same column are not significantly different among $10 \%$ protein groups (Tukey test, $\mathrm{p}<0.05$ ). "Difference statistically significant between $6 \%$ protein groups (unpaired Student's $t$ test, $\mathrm{p}<0.05$ ).

Table 5. True protein digestibility obtained in rats during the second week (seven days) of the experiment.

\begin{tabular}{lcccc}
\hline \multicolumn{1}{c}{ Diet } & Protein consumed $(\mathrm{g})$ & Fecal weight (dry, g) & Protein excreted (g) & True digestibility (\%) \\
\hline With 10\% protein & & & & \\
$\quad$ & & & \\
Reference & $10.85 \pm 1.58^{\mathrm{a}, \mathrm{b}}$ & $6.45 \pm 0.58^{\mathrm{b}}$ & $0.67 \pm 0.04^{\mathrm{b}}$ & $95.67 \pm 0.86^{\mathrm{a}}$ \\
Control & $9.31 \pm 1.00^{\mathrm{b}}$ & $6.39 \pm 0.88^{\mathrm{b}}$ & $0.70 \pm 0.17^{\mathrm{b}}$ & $94.76 \pm 1.56^{\mathrm{a}}$ \\
$\quad$ Germ & $11.82 \pm 0.74^{\mathrm{a}}$ & $30.00 \pm 2.24^{\mathrm{a}}$ & $3.00 \pm 0.11^{\mathrm{a}}$ & $76.35 \pm 0.99^{\mathrm{b}}$ \\
With 6\% protein & & & & \\
Control & $6.30 \pm 0.12$ & $6.56 \pm 0.24$ & $0.70 \pm 0.16$ & $92.23 \pm 2.60$ \\
Corn & $5.42 \pm 0.94$ & $7.50 \pm 1.29$ & $1.33 \pm 0.19^{*}$ & $80.90 \pm 3.02^{*}$ \\
\hline
\end{tabular}

Diets: reference - casein with $10 \%$ protein and $7 \%$ lipids; germ control - casein with $10 \%$ protein and $15 \%$ lipids; germ - germ fraction with pericarp with $10 \%$ protein and $15 \%$ lipids; corn control - casein with $6 \%$ protein; and corn - whole corn with $6 \%$ protein. ${ }^{\mathrm{a}, \mathrm{b}, \mathrm{c}} \mathrm{Data}$ are mean \pm standard deviation and means with the same letter in the same column are not significantly different among $10 \%$ protein groups (Tukey test, $\mathrm{p}<0.05$ ). * Difference statistically significant between $6 \%$ protein groups (unpaired Student's $t$ test, $\mathrm{p}<0.05$ ). 
germ group may have induced weight gain similar to that of its control (Table 4). The food and the protein consumption were significantly lower in the corn group than those of its control $(\mathrm{p}=0.0061$ and 0.0068 , respectively), which contributed to the lower weight gain in the former group, in addition to the fact that the corn protein is lysine-deficient (Table 3).

The Food Conversion Rate (FCR) ranged from 3.3 to 11.5 , as shown in Table 4 . The germ diet presented a greater FCR than that of the reference and germ control diets $(p<0.001)$. Therefore, the germ fraction was less efficient in promoting rat growth than the casein. On the other hand, this increase in FCR was only $33 \%$ compared to that of the germ control diet, which was below the FCR increase for the corn diet in relation to its control (123\%). The corn diet showed the highest value of FCR. A high food conversion rate was also observed in rats fed a corn diet with $7 \%$ protein $(9.6 \pm 1.1)$ for ten days compared to that of the control diet $(3.9 \pm 0.4)$ (NAVES et al., 2004). It shows the lowest dietary efficiency of the cereal-based diet in promoting growth.

The PER value determined for the germ fraction was about 20\% lower than that of the control and reference groups, and the PER value of corn was 50\% lower than that of casein $(\mathrm{p}=0.0001)$ (Table 4$)$. The corrected PER of the germ fraction was 2.07. Therefore, this fraction may be considered a source of good quality protein since the corrected PER was above $2.0(80 \%$ of the standard value of casein - 2.5) (FRIEDMAN, 1996). No PER value for corn germ protein was identified in the literature. The PER value of whole corn was higher than that reported in the literature $(\mathrm{PER}=1.18)($ FOOD..., 1970).

The true protein digestibility of the whole corn was higher than that of the germ fraction (Table 5), probably due to differences in protein content (lower for corn) and dietary fiber level (higher for germ) in the diets. Despite its lower digestibility, the germ fraction showed higher protein quality than that of the corn (Tables 4 and 6) due to its greater lysine content (Table 3). According to the FAO, the true digestibility of corn protein is $85 \%$ (FOOD..., 1991), and that of cooked maize germ is $80.8 \%$ (FOOD..., 1970), values close to those observed in this study.

The PDCAAS value was $86 \%$ for the germ fraction and $60 \%$ for the whole corn, results a bit higher than the values found by the RPER (Table 6). The PDCAAS method was recommended by the FAO as the most suitable method for evaluating the protein quality of vegetable foods (FOOD..., 1991), and more recently it was also recommended by the IOM (INSTITUTE..., 2005). In turn, the PER is the official method of the Association of Official Analytical Chemists (ASSOCIATION..., 1990) for evaluating

Table 6. Protein value of germ fraction with pericarp and whole corn.

\begin{tabular}{ccc}
\hline Protein source & \multicolumn{2}{c}{ Protein value (\%) } \\
\cline { 2 - 3 } & \multicolumn{1}{c}{ RPER } & PDCAAS \\
\hline Germ (with pericarp) & $77.1 \pm 2.9$ & $85.5 \pm 1.1$ \\
& $82.8 \pm 3.2$ & \\
Corn (whole kernel) & $48.6 \pm 10.7$ & $59.9 \pm 2.2$ \\
\hline
\end{tabular}

Data are mean \pm standard deviation; RPER: Relative Protein Efficiency Ratio (relative to reference and control diets, respectively, for germ); PDCAAS: Protein DigestibilityCorrected Amino Acid Score. protein quality. The literature reports a discrepancy between the values of biological indexes and of PDCAAS for a single protein source (FRIEDMAN, 1996; SOUSA et al., 2011). The PDCAAS may overestimate the nutritional value of a protein, whereas biological methods, such as the PER, which use growing rats, tend to underestimate the value of some vegetable proteins (SCHAAFSMA, 2000; YOUNG; PELLETT, 1994). In agreement to those reports, the RPER value of the germ with pericarp estimated in the present investigation (around 80\%) was lower than the PDCAAS value (86\%). In spite of this, both values indicate that the corn germ fraction with pericarp is a source of good quality protein, similar to that reported for Quality Protein Maize (QPM) (NAVES et al., 2004) and for corn and bean mixtures (ESTÉVEZ et al., 2003).

It should be emphasized that the nutritional and technological characteristics of the germ fraction with pericarp widen application options for the milling industry. However, the industrial processing of the corn should be conducted in accordance with hygienic-sanitary guidelines to obtain an adequate raw material for human consumption.

\section{Conclusions}

The corn germ fraction with pericarp is rich in dietary fiber and is a source of good quality protein and minerals (iron and zinc). It is recommended as a nutritive raw material in the formulation of food products for human consumption replacing corn (whole kernel or samp) and other cereals. Further studies on corn germ fraction with pericarp in processed food and its applicability and nutritional quality should be carried out.

\section{Acknowledgements}

The authors are grateful to Dr. José Cesar Rosa (Protein Chemistry Center of the University of São Paulo, Ribeirão Preto, Brazil) for the amino acid analyses, and to Milhão Alimentos Ltda (Inhumas, GO, Brazil) for the technical support in corn processing. The authors also acknowledge FUNAPE (Research Support Foundation, Federal University of Goiás, GO, Brazil) and $\mathrm{CNPq}$ (National Research Council, Brazil) for their financial support.

\section{References}

ALONZO, N.; HIRS, C.H.W. Automation of sample application in amino acid analyzes. Analytical Biochemistry, v. 23, n. 2, p. 272-288, 1968.

ASSOCIATION OF OFICIAL ANALYTICAL CHEMISTS - AOAC. Official methods of analysis. 15. ed. Arlington, 1990.

BLIGH, E. G.; DYER, W. J. A rapid method of total lipid extraction and purification. Canadian Journal of Biochemistry and Physiology, v. 37, n. 8, p.911-917, 1959.

BRITO, A. B. et al. Avaliação nutricional do gérmen integral de milho para aves. Ciência Animal Brasileira, v. 6, n. 1, p. 19-26, 2005.

ESTÉVEZ, A. M. et al. Evaluación nutricional y almacenamiento acelerado a $37^{\circ} \mathrm{C}$ de mezclas de frejol y maíz fritos. Archivos Latinoamericanos de Nutrición, v. 53, n. 1, p. 70-73, 2003. 
FOOD AND AGRICULTURE ORGANIZATION OF THE UNITED NATIONS - FAO. Amino-acid content of foods and biological data on proteins. Rome: FAO, 1970.

FOOD AND AGRICULTURE ORGANIZATION OF THE UNITED NATIONS - FAO. Protein quality evaluation. Rome: FAO, 1991. (FAO Food and Nutrition Paper, 51).

FRIEDMAN, M. Nutritional value of proteins from different food sources: a review. Journal of Agriculture and Food Chemistry, v. 44, n. 1, p. 6-29, 1996.

GRÅSTEN, S. M. et al. Fibers with different solubility characteristics alter similarly the metabolic activity of intestinal microbiota in rats fed cereal brans and inulin. Nutrition Research, v. 22, n. 12, p.1435-1444, 2002.

GUPTA, H.O.; EGGUM, B.O. Processing of maize germ oil cake into edible food grade and evaluation of its protein quality. Plant Foods for Human Nutrition, v. 52, n. 1, p. 1-8, 1998.

INSTITUTE OF MEDICINE - IOM. Food and Nutrition Board. Protein and amino acids. In: Institute of Medicine. Dietary references intakes for energy, carbohydrate, fiber, fat, fatty acids, cholesterol, protein, and amino acids. Washington, DC: The National Academies; 2005. p. 589-768.

INSTITUTO ADOLFO LUTZ - IAL Métodos físico-químicos para análise de alimentos. 4. ed. Brasília: Ministério da Saúde, 2005. (Série A. Normas e Manuais Técnicos).

LUCAS, B.; SOLETO, A. Effect of different alkalies, temperature, and hydrolysis times on tryptophan determination of pure proteins and of foods. Analytical Biochemistry, v. 109, n. 1, p. 192-197, 1980.

MARTINEZ-FLORES, H. E. et al. Effect of high fiber products on blood lipids and lipoproteins in hamsters. Nutrition Research, v. 24, n. 1, p. 85-93, 2004

MOORE, S.; SPACKMAN, D.H.; STEIN, W.H. Chromatography of amino acids on sulfonated polystyrene resins. Analytical Chemistry, v. 30, n. 7, p. 1185-1190, 1958.

NATIONAL RESEARCH COUNCIL - NRC. Manual sobre cuidados e usos de animais de laboratório. Goiânia: Association for the Assessment and Accreditation of Laboratory Animal Care International (AAALACI); Colégio Brasileiro de Experimentação
Animal (COBEA), 2004. 162 p. (Tradução de Guide for the care and use of laboratory animals).

NAVES, M. M. V. et al. Avaliação química e biológica da proteína do grão em cultivares de milho de alta qualidade protéica. Pesquisa Agropecuária Tropical, v. 34, n. 1, p. 1-8, 2004.

PELLETT, P.L.; YOUNG, V.R. Nutritional evaluation of protein foods. Tokyo: The United Nations University, 1980.

PIRES, C. V. et al. Qualidade nutricional e escore químico de aminoácidos de diferentes fontes protéicas. Ciência e Tecnologia de Alimentos, v. 26, n. 1, p. 179-187, 2006.

PROSKY, L. et al. Determination of insoluble, soluble, and total dietary fiber in foods and foods products: interlaboratory study. Journal of the Association of Official Analytical Chemistry, v. 71, n. 5, p.1017-1023, 1988.

REEVES, P.G.; NIELSEN, F.H.; FAHEY JR., G.C. AIN-93 purified diets for laboratory rodents: final report of the American Institute of Nutrition ad hoc Writing Committee on the Reformulation of the AIN-76A Rodent Diet. Journal of Nutrition, v. 123, n. 11I, p. 1939-1951, 1993.

SCHAAFSMA, G. The protein digestibility-corrected amino acid score. Journal of Nutrition, v. 130, n. 7, p. 1865S-1867S, 2000. (suppl.).

SHEWRY, P.R. Improving the protein content and composition of cereal grain. Journal of Cereal Science, v. 46, n. 3, p. 239-250, 2007.

SOTELO, A. et al. Amino acid content and protein biological evaluation of 12 Mexican varieties of rice. Cereal Chemistry, v. 71, n. 6, p. 605-609, 1994.

SOUSA, A. G. O. et al. Nutritional quality and protein value of exotic almonds and nut from the Brazilian Savanna compared to peanut. Food Research International. In press. Disponível em: $<$ http://dx.doi.org/10.1016/j.foodres.2011.02.013>. Acesso em: 30 mar. 2011.

WATSON, S. A; RAMSTED, P. E. (Ed.). Corn: chemistry and technology. Saint Paul: American Association of Cereal Chemists, 1999.

YOUNG, V. R.; PELLETT, P. L. Plant proteins in relation to human protein and amino acid nutrition. American Journal of Clinical Nutrition, v. 59, n. 5, p. 1203S-1212S, 1994. (suppl.). 